\title{
Auditors and Corporate Governance: Evidence from the Public Sector
}

\author{
Mark Schelker*
}

\section{INTRODUCTION}

Corporate auditors review financial statements and evaluate the accuracy of the information provided, which is crucial for investors and other stakeholders of a firm. It seems intuitive that auditors evaluating financial statements should be competent as well as independent from the firms' management who is providing exactly this information. However, the lack of auditor independence or expertise was of major importance in the recent history of corporate governance. After the giant accounting scandals (e.g., Enron, Tyco, Worldcom, Parmalat, etc.), which culminated in the collapse of Arthur Andersen, there has been a growing call for tougher corporate governance provisions in general and specifically for improved auditor independence.

Most famously these developments resulted in the 'Public Company Accounting Reform and Investor Protection Act of 2002' better known as the 'SarbanesOxley Act' in the United States. The Sarbanes-Oxley Act together with other corporate governance rules installed at e.g., the New York Stock Exchange (NYSE), the American Stock Exchange (AMEX), or the NASDAQ require the board committee appointing the auditor to be composed entirely of outside directors. Although the Sarbanes-Oxley Act did not establish mandatory auditor rotation, it required the Government Accountability Office (GAO) to analyze such procedures (GAO 2003), and finally implemented a weakened form, namely mandatory rotation of the lead partner within an auditing firm. Mandatory auditor rotation is heavily debated among audit experts, academics, policy makers, and management boards. Proponents of mandatory auditor rotation argue that long-term relationships between auditors and their clients impede auditor independence. Therefore, auditors should only have limited mandates. Opponents of such rotation point out that rotation would make things worse. New auditors need time to acquire the relevant information and expertise to

* Department of Economics, University of St. Gallen. SIAW-HSG, Bodanstrasse 8, 9000 St. Gallen, Switzerland, Email: mark.schelker@unisg.ch. I would like to thank Reiner Eichenberger, Bruno Frey, and Andrei Shleifer for feedback and comments. 
effectively audit a firm. They argue that audit failures typically occur in the first few years of a mandate. It is an empirical question to determine the effect of mandatory auditor rotation. However, most studies encounter serious empirical challenges, because not many countries have adopted such rotation rules, and troubled firms might change auditors strategically. Managers are likely to have incentives to switch to 'incompetent' auditors (e.g., auditors new to the industry) when problems occur. Hence, it is extremely difficult to determine the impact of auditor tenure and mandatory auditor rotation by analyzing the corporate sector. The endogeneity of auditor replacement as well as selection effects are serious threats to valid inference.

This contribution is an attempt to openly discuss important (empirical) challenges to the analysis of auditor tenure and rotation requirements. I propose considering evidence from the public sector, where the basic mission of the auditor and principal-agent relationships are similar, but the empirical challenges are less daunting. In order to obtain useful insights from the public sector, I analyze the similarities of the agency relationship in the public and the corporate sector, and discuss critical issues. The empirical investigation relies on public auditing institutions at the US state level, where state auditors are often appointed for a fixed term. I take advantage of differences of the predetermined term length and of auditor term limit legislation. A term limit is essentially a mandatory auditor rotation requirement on the chief auditor.

Section II introduces the main arguments and literature in the context of auditor independence and auditor expertise in the corporate sector. I present the main pros and cons of mandatory auditor rotation and review the empirical evidence on corporate auditors. After comparing the similarities between the public and the corporate sector, Section III introduces the US public sector, which I use to conduct the empirical study. In Section IV, I discuss the data and the empirical strategy and present results. Section V summarizes and concludes.

\section{CORPORATE AUDITORS: EXPERTISE AND INDEPENDENCE}

The agency problem between the owners and the management of a firm is at the heart of the corporate governance literature. ${ }^{1}$ The main question is how investors (the principals) can make sure that they are not expropriated by the management (the agents). Disclosure requirements, independent review, and legal enforcement are key factors to reduce this principal-agent problem. Without accurate and timely information, shareholders, creditors, and any other stakeholder group will find it difficult to make adequate decisions. However, if the management is unconstrained and in sole charge of providing information, there is a high risk

1. Important contributions taking this view are e.g., Jensen and Meckling (1976), Fama and Jensen (1983), Prendergast (1999), or more recently Bebchuk and Fried (2003). Shleifer and Vishny (1997) and Becht, Bolton and Röell (2003) provide excellent surveys of the field. 
that this information serves management interests and is not necessarily accurate. Therefore, disclosure requirements must be backed by independent review and legal rules allowing private litigation in the case of non-compliance. ${ }^{2}$ Review of financial information is usually conducted by certified and independent private auditing firms. They are supposed to verify and certify financial statements issued by a company's management. In this context two factors seem to be important: auditor expertise and auditor independence.

\section{Auditor expertise}

One of the main drivers of the effectiveness of any review of disclosed information depends on audit quality, which itself depends on auditor expertise. If more competent auditors detect inaccurate reporting and financial data management with a higher probability, the informational content of financial information improves, which enables investors to make more appropriate investment decisions. The literature typically has to rely on indirect measures of audit quality. One such measure is whether the audit is conducted by one of the big accounting firms (e.g., Mansi, Maxwell and Miller 2004, Ferguson, Francis and Stokes 2003, Lai 2009). The (at least implicit) assumption is that big accounting firms have stronger incentives to establish a quality reputation in the market and might be more successful in attracting talent. Typically, it is found that firms which are audited by one of the major accounting firms have less opportunity for earnings management. Often expertise is approximated with experience or tenure because auditors might need some time to familiarize with firm and industry specificities. An alternative measure is used by Caramanis and Lennox (2008) who analyze the influence of audit effort - measured as actual hours worked by the auditors - on earnings management. They find that low audit effort increases the probability for and size of positive abnormal accruals.

\section{Auditor independence}

Review by a corporate auditor only reduces the agency problem between the investors and the management if collusion of the management and the auditor is

2. For evidence on the role of disclosure requirements and private litigation see La Porta, Lopez-de-Silanes and Shleifer (2006). They examine securities laws that improve transparency, make contracting between firms and investors easier, reduce costs of resolving disputes and, thus, encourage financing through equity. They analyze disclosure requirements and liability standards in securities laws in a cross-section of countries and find strong evidence that disclosure requirements and liability standards promote financial market development. 
not likely. ${ }^{3}$ A first step towards reducing the risk of collusion is to keep the auditor independent from the management, eliminating the most obvious channels for side-payments and reciprocal behavior. In order to provide an unbiased and impartial view on financial statements, legal provisions usually require that financial reports are audited by some external professional body, not directly linked to the company. However, independence is not guaranteed by the requirement that the auditor must come from an outside company. There are numerous additional threats to auditor independence, starting with the entanglement of audit and non-audit services provided by an accounting firm to the same client, appointing and removal procedures as well as psychological ties to the appointing body.

Audit and non-audit services: Providing audit and certain non-audit services (e.g., consulting services) to a client at the same time has been prohibited by the Sarbanes-Oxley Act. Prior to that prohibition accounting firms were able to offer audit services below cost, because lucrative consulting services compensated for the incurred losses from audit services (e.g., Levitt 2000). Such entanglement can impair independent review of financial statements by the auditing and consulting firm.

Appointing and removal procedures: Auditor independence might be heavily influenced by the appointing procedure of the corporate auditor (e.g., Acemoglu and Gietzmann 1997, Mayhew and Pike 2004). Independence is hardly achieved if the management itself is appointing the auditor - its own supervisor - or if it has a big stake in the (re)appointment process. Permitting the management to appoint its auditor increases the risk of collusion because the appointing process introduces a direct channel for side-payments and reciprocal behavior. Even though this risk is well understood, in many companies the top management is heavily involved in the appointing process. Even if the CEO does not choose the auditor single-handedly, he frequently nominates the corporate auditor, and the board of directors only confirms or rejects the CEOs' choice. ${ }^{4}$ If the board of directors appoints the auditor it is important that the board is dominated by independent outside directors instead of inside directors or the CEO himself. ${ }^{5}$ Klein (1998) provides evidence that firm performance is positively correlated with the dominance of outside directors in the audit and compensation commit-

3. E.g., Antle (1984), Tirole (1986), Baiman, Evans and Nagarajan (1991), Kofman and Lawarrée (1993), Aghion and Tirole (1997), Bolton and Dewatripont (2005), and Khalil and Lawarrée (2006) analyze the incentives for the supervisor (e.g., auditor) to collude with the agent (e.g., management).

4. One of the most far-reaching proposition is to let shareholders directly choose the auditor in regular competitive elections at the general assembly (e.g., Schelker and Eichenberger 2003, Frey and Benz 2005, Bebchuk 2007, Benz and Frey 2007, and for experimental evidence e.g., Mayhew and Pike 2004).

5. On the influence of the size and composition of the board of directors see e.g., Weisbach (1988), Hermalin and Weisbach (1998), Klein (1998), or Shivdasani and Yermack (1999), Beiner, Drobetz, Schmid and Zimmermann (2004). 
tee. Recently, the Sarbanes-Oxley Act together with corporate governance rules imposed by the NYSE, the NASDAQ, and the AMEX require that the board of directors of companies with stocks listed in the United States be composed of a majority of outside directors. They further impose that the audit committee consists entirely of outside directors with at least one having financial expertise (Agrawal and Chadha 2005). ${ }^{6}$

As important as hiring, is firing. Thus, removal procedures might also influence auditor independence. If the management is authorized to change the auditing firm at will, auditors' incentives become aligned with the management and audit services might be biased in favor of the agent that is being monitored. If the management is able to influence both hiring and firing, the resulting threat to dismiss the auditor can have considerable effects on auditor independence. In the extreme case the management actively searches for a 'friendly' auditor, which is sometimes referred to as 'audit shopping' (e.g., Davidson III, Jiraporn and DaDalt 2006). Therefore, a natural device to reduce agency problems might be to let investors directly choose the auditor. Mayhew and Pike (2004) analyze auditor selection and its influence on auditor independence in an experimental framework. They specifically analyze if investor selection of the auditor enhances independence. In their experimental framework they are able to manipulate who hires the auditor and they measure the influence of the selection mechanism on auditor objectivity. They find strong evidence for increased objectivity of the audit report if auditors are directly chosen by investors. This experimental approach is especially interesting because such a setting does not exist in the 'corporate world'.

Psychological ties to the appointing body: Another less discussed threat to auditor independence comes from psychological ties between the auditor and the appointing body. Bazerman, Loewenstein and Moore (2002) argue that people are vulnerable to unconscious bias in favor of the appointing body. "Psychological research shows that our desires powerfully influence the way we interpret information, even when we're trying to be objective and impartial." (Bazerman, Loewenstein and Moore 2002: 98). In a series of experiments they show that individuals evaluate the same facts systematically differently if tied (e.g., hired) to different bodies. Individuals do not even need to have strong ties to some party. In order to observe such bias it is sufficient that they are loosely connected (e.g., a hypothetical professional relationship is sufficient). They ran experiments with professional auditors asking them to evaluate the accounting of five reports. Half of the group where told that they should assume they were hired by the company to be audited and the other half should assume they were hired by some different company doing business with the firm under audit. Auditors assuming

6. Agrawal and Chadha (2005) provide empirical evidence that boards containing outside directors with financial expertise reduce the probability of earnings restatements. 
they were hired by the firm under review attested full compliance with GAAP with a 30 percent higher probability in all five cases. The authors conclude that "[. . .] even the suggestion of a hypothetical relationship with a client distorts an auditor's judgments." (Bazerman, Loewenstein and Moore 2002: 101). They argue that reforms must target auditors' incentives to please a client. From this perspective they are in favor of the provision of the Sarbanes-Oxley Act prohibiting consulting services to companies under audit. The authors go even further and propose that auditors should be hired for a predetermined period with no possibility of rehiring.

\section{Auditor independence and mandatory auditor rotation: The main pros and cons}

One of the most prominently discussed approaches to improve auditor independence is mandatory auditor (audit partner) rotation. ${ }^{7}$ Such provisions require companies to change the auditor at regular predetermined intervals. The Sarbanes-Oxley Act takes one step in this direction by requiring the rotation of the responsible lead partner within an auditing firm. The dispute on this issue among auditing experts, academics, and policymakers is contentious. ${ }^{8}$

At the core of the discussions is the trade-off between improving auditor independence and the associated costs of forgoing auditor expertise. Independence seems to be crucial to ensure high audit quality, but so is expertise. The main question to address is how to preserve or improve independence without too big a loss of expertise. A straightforward implication is to let the principal, the investors select the auditor. This would tie the auditor more to the investors and less to the management without losing expertise due to mandatory rotation. Mayhew and Pike (2004) show in their experimental setting that investorselected auditors indeed remain more independent. However, we still have to consider that over time the ties with management might become strong. Therefore, rotation might still be an issue.

Proponents of auditor rotation emphasize the positive effects of rotation on auditor independence, which reduces agency problems and increases the credibility of financial reports (e.g., Dopuch, King and Schwartz 2001, Gietzmann and Sen 2002). From this perspective mandatory rotation enhances auditor

7. Rotation requirements are also important in other situations in which a monitor is supposed to provide information to a principal who himself cannot obtain such information directly. E.g., Hertzberg, Liberti and Paravisini (2010) show that bank policy often requires some form of rotation of loan officers. They argue that the reassignment of loan officers to different borrowers provides incentives to disclose bad information.

8. E.g., Dopuch, King and Schwartz (2001), Gietzmann and Sen (2002), Myers, Myers and Omer (2003), Mansi, Maxwell and Miller (2004), Comunale and Sexton (2005), and Gosh and Moon (2005), Chen, Lin and Lin (2008). A literature review is provided by Cameran, di Vincenzo and Merlotti (2005) and Casterella and Johnston (2013). A comparison between firm vs. partner rotation is provided by Kaplan and Mauldin (2008). 
independence because managers cannot directly threaten auditors with dismissal and cannot promise future income due to reappointment. Furthermore, it is sometimes suggested that extended client-auditor relationships alone impede on auditor independence. The negative effect of extended auditor tenure stems from evolving ties between auditor and client. ${ }^{9}$ This argument is underlined by psychological evidence provided by Bazerman, Loewenstein and Moore (2002), who suggest stronger psychological bias with increasing ties between client and auditor. Moreover, 'low-balling' is also constrained by rotation requirements. 'Low-balling' refers to audit firms offering fees that are lower than the marginal costs of the initial engagement with a new client. Such an offer is interesting if the audit firm anticipates declining marginal costs of future audits if it is rehired (Dopuch, King and Schwartz 2001). Mandatory rotation would also be a fix for such practices.

Opponents argue that mandatory auditor rotation is not costless (e.g., Mansi, Maxwell and Miller 2004, Johnson, Khurana and Reynolds 2002, Chen, Lin and Lin 2008). They point out that changing the corporate auditor involves a loss of expertise because the new auditor does not know the company well and must first acquire the relevant company- and industry-specific know-how. This lack of expertise in the beginning of a mandate may lead to information asymmetries between auditor and client and increased audit failure. Such failure worsens the agency problem and weakens credibility of financial statements. Johnson, Khurana and Reynolds (2002) even argue that as audit-client relationships endure, auditors become more independent, because due to experience and client-specific knowledge, the auditor depends less on management information. Furthermore, it is argued that voluntarily changing the auditor contains information. Because there are a number of reasons why firing the auditor and engaging a new firm is beneficial to shareholders - if the change occurs because the auditor was e.g., not efficient, extremely conservative, or qualitatively inferior - the change of an auditor may provide information to the market. It could also be that a firm changes from a small audit firm to a big 4 audit firm, which is often considered a step towards higher quality audit (e.g., Mansi, Maxwell and Miller 2004).

Most studies cannot directly analyze the influence of rotation requirement on outcomes because there are not many countries which actually implemented

9. Arel, Brody and Pany (2005: 36) describe the close relationship between Enron employees and the employees of its auditor Arthur Andersen: "Andersen auditors and consultants were given permanent office space at Enron headquarters here and dressed business-casual like their Enron colleagues. They shared in office birthdays, frequented lunchtime parties in a nearby park and weekend fund-raisers for charities. They even went on Enron employees' ski trips to Beaver Creek, Colo." For an account of the Enron scandal see, e.g., McLean and Elkind (2003), for how trust-networks and close relationships undermined corporate governance at Enron see, e.g., Currall and Epstein (2003) and Latusek and Cook (2012). 
mandatory auditor rotation. ${ }^{10}$ Hence, most empirical studies focus on the impact of auditor tenure on outcome variables, such as audit quality perception of investors, market valuation, earnings quality, the likelihood of earnings restatements, etc. Mansi, Maxwell and Miller (2004) report that longer tenure results in lower cost of debt financing, measured by S\&P credit ratings and credit spreads. Various further studies report positive correlations between auditor tenure and real and perceived earnings quality (e.g., Johnson, Khurana and Reynolds 2002, Myers, Myers and Omer 2003, Gosh and Moon 2005, Chen, Lin and Lin 2008, Jenkins and Velury 2008) and to a lesser extent Gul, Fung and Jaggi (2009).

Overall, these results suggest that longer tenure increases expertise, which might compensate negative effects from potentially diminishing independence over time. However, if both aspects, expertise and independence, are important one could think of an inverse U-shape relationship between audit quality and tenure: Due to learning audit quality is first increasing with tenure and after a certain period of time it is decreasing because of diminishing independence. Such a quadratic relationship is not captured in standard linear estimation models.

\section{Empirical challenges}

In empirical settings analyzing real-world data one major drawback is that auditor rotation seems clearly endogenous to auditor behavior and firm specific developments, and not the result of exogenously determined rules. Even though most studies carefully explore the data and try to address some sources of endogeneity they often cannot actually analyze auditor tenure in an environment with exogenously determined auditor tenure length and auditor rotation. In the rare case an auditor rotation requirement is implemented, e.g., South Korea or Italy, there is typically no directly comparable counterfactual at hand because the rotation requirement is binding for all companies with certain characteristics.

If auditor tenure is the main variable of interest we have to keep in mind that tenure is determined (or at least heavily influenced) by the management under audit. Thus, auditor changes are likely to be motivated by firm-specific developments and are endogenous. For instance, in the most optimistic case the auditor is changed because the management would like to have a more competent auditor. However, this suggests that the change occurs because auditor performance is weak. In contrast, scenarios in which troubled firms switch to incompetent auditors to hide shortcomings from investors could bias results in

10. Exceptions are Italy, Brazil, South Korea, Singapore and India which (partially) implemented mandatory auditor rotation. For more details see Cameran, di Vincenzo and Merlotti (2005). 
the other direction. In this case increasing audit failure would be wrongfully attributed to auditor rotation. The simple fact that managers can influence auditor rotation obstructs valid inference.

The severe endogeneity problems motivate Dopuch, King and Schwartz (2001) to conduct empirical research in an experimental setting. They analyze four different treatments: (1) one treatment does not require auditor rotation or retention, (2) one requires auditor retention, (3) one requires rotation only, and (4) one treatment requires both rotation and retention of the auditor. They report that rotation requirements in the third (requiring rotation) and forth treatment (requiring rotation and retention) impact positively on auditor independence. Church and Zhang (2006) address the problem of mandatory auditor rotation theoretically because they also acknowledge the severe empirical problems occurring when analyzing this specific problem. Similar to the experimental setting they find that mandatory auditor rotation can improve auditor independence. However, the results are sensitive "[. . .] to the rotation period, start-up costs, the costs associated with biased reports, auditors' learning, and the time span of managers' incentives." (Church and Zhang 2006: 3).

Overall the existing empirical evidence on the impact of auditor tenure suggests that longer tenure impacts positively on outcome measures. However, due to the mentioned severe endogeneity problems I propose to learn from evidence in the public sector, in which auditors play as similar role but empirical hurdles are less daunting.

\section{AUDITORS IN THE PUBLIC SECTOR}

\section{Analogies between the corporate and the public sector}

The principal-agent problem is not unique to the corporate sector. By starting their article with the statement "Corporations are republics." Gompers, Ishii and Metrick (2003: 107) make a strong statement highlighting the similarity between the corporate and the public governance systems. They continue their view of corporations as shareholder democracies, and write:

"[...] The ultimate authority rests with voters (shareholders). These voters elect representatives (directors) who delegate most decisions to bureaucrats (managers). As in any republic, the actual power-sharing relationship depends upon the specific rules of governance. One extreme, which tilts toward a democracy, reserves little power for management and allows shareholders to quickly and easily replace directors. The other extreme, which tilts toward a dictatorship, reserves extensive power for management and places strong restrictions on shareholders' ability to replace directors." Gompers, Ishii and Metrick (2003: 107)

The fundamental agency problem shareholders face is essentially similar to the one voters face in a democracy. There the agents also have considerable leeway to maximize their own instead of the principals' utility. The control 
problems are extensive in both the corporate and the public sector. Both delegate extensive powers to some few agents, whereas the principal consists of a large group of individuals facing a collective action problem to control the agents. Shareholders as well as voters are both required to take action through the voting mechanism, but individuals have only limited incentives to bear information costs and engage in costly actions against the agent to protect the interest of all other principals as well. Thus, controlling the agents requires overcoming the free-rider problem, acquiring information, and orchestrating possible countermeasures, such as coordinated voting against decisions taken by the agents, etc.

Frey and Benz (2005) and Benz and Frey (2007) go beyond the pure resemblance and suggest that due to the existing similarities, corporate governance might learn from the rich literature on public governance. Agency theory is an important theoretical approach in both corporate and public sector economics and there are many institutional similarities. All public entities in developed countries are subject to disclosure requirements and independent review by an auditor. Disclosure is important because without such transparency the principal has no means of controlling the agent. Alt and Lassen (2006) provide evidence for the importance of disclosure requirements in the policy making process and show that increased fiscal transparency reduces public deficits and debt accumulation. ${ }^{11}$ Independent review of financial reports is also an important issue in the public sector. Olken (2007) presents evidence from a field experiment in Indonesia suggesting that an increase in audit probability reduces misreporting of expenditures in the public sector. For the same reasons as in the literature on the corporate sector, the scarce literature on public auditing focuses on auditor independence (Schelker 2008, 2012a). Without an independent auditor it would be difficult for creditors and citizens to assess the quality of financial statements. All developed countries feature some form of audit institution reviewing financial statements provided by the government. In some federal countries such as the US the sub-federal governments, e.g., the states or municipalities, feature their own auditing institution. Thus, I believe that - regarding the role of auditing institutions - the analogy is strong, and analyzing the public sector might provide useful insights.

\section{US state auditors}

In order to analyze the influence of auditor terms and term limits I take advantage of the decentralized US federal structure. The US states enjoy a high degree of autonomy and every state has its own constitution that defines the primary governance structures and processes. The main advantage in this setting is that

11. For further theoretical analyses of transparency in the public sector see e.g., Besley and Smart (2007, Gavazza and Lizzeri (2009). 
the states feature different regulations concerning the institutional details of their auditing institution. Variation can be observed on various dimensions, notably in the professional education requirements, auditor term length and term limits as well as in appointing and removal procedures. The main advantage over data from the corporate sector stems from the fact that auditor characteristics are determined by either the state constitution or state laws and are as such 'exogenous' from the perspective of the audited agent. This is an important advantage since the audited agent cannot strategically influence the timing of an auditor change. Hence, e.g., the term length or a term limit is not endogenous to actual auditor performance.

Auditor term length and mandatory auditor rotation: In contrast to corporate auditors, most US states auditors are not appointed for an open mandate, but for a fixed term that varies in length across states (Schelker 2012a). Since it is often argued that longer auditor tenure impedes independence - the main argument for auditor rotation - I analyze the influence of different official term lengths on public sector performance. Most commonly state laws define a fixed term length $(2,4,5,6,7,8$, or 10 years) after which the auditor-principal relationship ends. I have no clear-cut expectations for the influence of longer auditor terms on public sector performance, since there are arguments pointing towards inefficiencies due to lower independence as well as towards benefits from more expertise. I examine if there are non-linear (quadratic) effects of auditor tenure on performance. Auditor performance might be weak in the beginning due to a lack of firm-specific expertise, then increases due to learning, and decreases with continuing engagement due to dwindling independence.

Some states allow their auditors to reapply for the position and some states impose a binding term limit. A term limit is comparable to mandatory auditor rotation, because the auditor cannot run for office after the predetermined fixed term is over, irrespective of its performance. More strictly speaking, an auditor term limit affects the head of the state auditing office and, hence, is comparable to a mandatory change of the lead partner of an audit firm. This is similar to the requirement adopted with the Sarbanes-Oxley Act. Unfortunately, I cannot study the effect of a change of the entire audit apparatus.

If the auditor can reapply for the job, but the selection process is open to challengers and not in the hands of the audited agent, the mechanism could preserve audit expertise without impeding independence too much. Of course it is also important whether the auditor can be dismissed during its term. Thus, I control for differences in the procedures to dismiss the auditor. Removal procedures could be a mechanism to keep the auditor in line with the interests of the appointing body.

Auditor expertise: The public auditing institution is typically a large bureaucracy and it would be very difficult to assess the expertise within such a complex structure. Hence, I focus on the influence of the expertise and competence of the 
chief auditor. Public auditing institutions are headed by the chief auditor, who is responsible for the overall activity and performance of the agency. Several departments with specialized auditing and administration staff conduct the various audits. The chief auditor could be compared to the lead partner of a big auditing firm, who is responsible for the audit mandate and audit policy, but is not necessarily directly a part of the actual auditing process. He defines the auditing policy and auditing strategy and he typically enjoys a high degree of autonomy within the legal and regulatory framework. He can usually influence the focus of the conducted audits, its timing, priorities and the thoroughness of it. The auditing staff conducts the audits according to the auditing policy and a well-defined regulatory framework. They have to follow a clear auditing mission that is tightly regulated by standardized procedures (Schelker 2012b). I approximate auditor expertise by state requirements for the chief auditor to hold a professional degree as a Certified Public Accountant (CPA).

Auditor selection mechanism: US state auditors are elected by the citizens or appointed by either the legislative or the executive branch. Executive appointment is rare (CA and $\mathrm{CO}$ ) and I will control for this difference in the empirical analysis. In the case of elected or legislative appointed auditors the agent (executive) can neither directly select the auditor nor influence it by promising future (re)appointment. ${ }^{12}$ It needs to be evaluated whether the analogy is instructive for our purposes. Experimental evidence for the corporate sector indicates that investor (principal) selection improves auditor performance (Mayhew and Pike 2004). In our specific case this would correspond to the direct election of the auditors by the citizens. Alternatively, the auditor could be selected by the legislature, which could somehow correspond to the selection of the auditor by an independent board of directors. However, the members of the board of directors are generally not elected in competitive elections. From this perspective it seems unclear whether we can directly learn from empirical findings in the public sector. Hence, this will not be the main focus of the empirical investigation, although I will always control for this structural difference.

\section{EMPIRICAL EVIDENCE FROM THE PUBLIC SECTOR}

\section{Data}

In order to conduct the empirical analysis I adopt a unique dataset containing information on a variety of institutional details of US state auditing institutions (see Schelker 2008) and combine it with a standard set of state controls (see Alt, Lassen and Rose 2006). In addition to the information on various characteristics of the US state audit offices, the dataset contains a whole battery of state specific

12. For a discussion of auditor selection mechanisms and empirical evidence see Schelker (2008). 
variables ranging from information on fiscal performance, state institutions such as balanced budget requirements, voter initiatives, etc. to population and income data. The panel dataset contains state-specific information between 1990 and 1999. More details and summary statistics can be found in the Appendix. The empirical analysis reports results partially based on Schelker (2012a,b).

Officially reported fiscal information such as expenditures, revenues, deficits, or debt is likely to be unreliable, because the quality of the information itself depends on audit quality (Schelker 2008, 2012a,b). Hence, data quality is endogenous to auditor characteristics. Moreover, high as well as low levels of expenditure and debt might be the outcomes of good or bad governance respectively, since e.g., especially efficient governments might face a higher demand for public goods relative to inefficient governments (e.g., Ferejohn 1999). Therefore, I resort to state long-term credit ratings that reflect a market evaluation of state fiscal performance (for similar approaches see e.g., Johnson and Kriz 2005, Depken and Lafountain 2006). Audits are the natural complement to disclosure requirements and provide valuable information to investors. More credible fiscal information should improve the creditworthiness and reduce the cost of capital. The approach taken is comparable to Mansi, Maxwell and Miller (2004) who rely on S\&P credit ratings in their empirical investigation on corporate auditors. In order to tease out the market evaluation of anticipated audit quality I control for the influence of the reported state of public finance and I include real per capita state debt accumulation as a covariate in the empirical analysis.

The data on state credit ratings are collected from Moody's Investor Services, Fitch Ratings and Standard \& Poor's. State general obligation bond ratings are available for a maximum of 42 US states for some or the entire period 19901999 , but do not include states that have no general obligation debt. ${ }^{13}$ When observing states without General Obligation Bond (GOB) ratings, selection bias might be a concern. When approaching this potential selection problem, I do not find a significant correlation between auditor characteristics and the excluded states. Furthermore, I cannot explain any of this selection with the auditor or institutional variables in a regression framework either. Hence, it seems that selection bias is not a major concern for the study. In the context of this study a further, though minor, adjustment is the exclusion of Alaska and Hawaii from the analysis, which is the general practice for studies analyzing fiscal institutions in US states. Alaska and Hawaii are outliers in many respects, but most importantly with regard to the fiscal situation, since these states depend disproportionally on federal transfers. Given the available data, the exclusion of Alaska and Hawaii

13. The states without any rating during the analyzed period are Arizona, Colorado, Iowa, Idaho, Nebraska and South Dakota. 
does not affect the results associated with auditor term and term limits in the present study, while it enables the readers to compare the results to related work using fiscal data at the US state level.

The construction of the credit rating variable follows the approach suggested by Depken and Lafountain (2006) and implemented by Schelker (2012a,b). The three principal rating agencies (Moody's, Standard \& Poor's, and Fitch) rate State General Obligation Bonds. Unfortunately, it was not possible to receive Standard \& Poor's (S\&P) ratings prior to $1995 .{ }^{14}$ Hence, the ratings from 1992 to 1994 have to rely on ratings provided by Moody's and Fitch. The agencies use very similar rating scales. S\&P and Fitch use a rating scheme that ranges from AAA to D including 22 rating categories, while Moody's rates GOBs according to a rating ranging from AAA to $\mathrm{C}$ with 21 categories. In order to construct a single credit rating measure including all available rating information I first assign every rating category a score between -1 and -21 in the case of Moody's and -22 in the case of Fitch and S\&P. Following the notation by Depken and Lafountain (2006) the numerical rating for State $i$ in year $t$ by rating agency $j$ is $R_{i t j} \in\left\{-1, \ldots,-N_{j}\right\}$, where -1 corresponds to the highest GOB rating and $-N_{j}$ the lowest GOB rating by agency $j .{ }^{15}$ In a second step I normalize these scores $R_{i t j}$ by dividing them by the number of possible ratings $N_{j}$ for each rating agency $j=1, \ldots, n$ to obtain $R^{\prime}{ }_{i t j}=R_{i t j} / N_{j}$. In a last step I average the available normalized rating scores $R_{i t j}^{\prime}$ to obtain a normalized overall rating $R_{i t}$ for each State $i$ in year $t$. The normalized state-year rating then is $R_{i t}=\frac{1}{n} \sum_{j=1}^{n} \frac{R_{i t j}}{N_{j}}$ and it varies between -1 and 0 . Since not all State GOB are always rated by all three rating agencies, some State rating measures rely only on two or in some cases one agency. This however, is only the case for a minority of all states and years, but could not be circumvented.

\section{Empirical strategy}

In the interest of consistency, I first present regression results using the actual tenure length. This is in principle close to what has been estimated so far in most of the corporate literature. Auditor tenure however, is directly dependent on auditor behavior as well as institutional provisions such as whether the auditor serves at the pleasure of some appointing body or rather for a fixed term length, term limits, and procedures to remove an auditor from office. It becomes imme-

14. Moody's Investor Services and Fitch Ratings directly provided the data used in this study. The S\&P ratings could not be received from S\&P. However, S\&P rating information could be gathered from the US Census Bureau from 1995-1999.

15. According to this scale the ratings are categorized as follows: $\mathrm{AAA}=-1$ to $\mathrm{C}=-21$ (lowest rating for Moody's) and $\mathrm{D}=-22$ ( $\mathrm{S} \& \mathrm{P}$ and Fitch). The negative signs only serve the purpose to make it easier and more intuitive for the reader to interpret the regression results. 
diately apparent that such regressions produce biased estimates. One way of dealing with this endogeneity problem would be to estimate instrumental variable models. This however, is rather difficult since finding valid instruments is extremely challenging.

I estimate the following general specification:

$$
R_{i t}=\alpha+\beta_{1} \text { tenure }_{i t}+\boldsymbol{A}_{i t} \gamma+\boldsymbol{X}_{i t} \boldsymbol{\delta}+\mu_{t}+\varepsilon_{i t}
$$

where $R_{i t}$ is the general obligation bond rating in state $i$ in year $t$, tenure $_{i t}$ is the tenure length (in years) of a state auditor, $\boldsymbol{A}_{i t}$ is a vector of auditor characteristics and $\boldsymbol{X}_{i t}$ is a vector of state control variables. The subscripts $i=1, \ldots, n$ and $t=1$, $\ldots, T$ always indicate the state and year, respectively.

In a second step, I resort to measures which are not directly determined by the auditor or the auditee, but are predetermined features of a state's institutional design. The design of state auditing institutions is defined in the state constitution or in state laws. I present empirical results on the influence of auditor term length as well as of auditor term limits on credit ratings (see also Schelker 2012a). I examine the discussed linear and potential non-linear relationship of term length on outcomes.

$$
\begin{aligned}
R_{i t}= & \alpha+\beta_{1} \text { term length }_{i t}+\beta_{2}\left({\text { term length })^{2}}_{i t}+\beta_{3} \text { term limit }_{i t}+\boldsymbol{A}_{i t} \boldsymbol{\gamma}+\right. \\
& \boldsymbol{X}_{i t} \boldsymbol{\delta}+\mu_{t}+\varepsilon_{i t}
\end{aligned}
$$

Third, I add a variable capturing auditor expertise - which is measured by the existence of a minimal professional education requirement (CPA, Certified Public Accountant) for the chief auditor - to the previous model specifications (see also Schelker 2012b).

$$
\begin{aligned}
R_{i t}= & \alpha+\beta_{1} \text { expertise }_{i t}+\beta_{2} \text { term length }_{i t}+\beta_{3}\left(\text { term length }_{i t}\right)^{2}+ \\
& \beta_{4} \text { term limit }_{i t}+\boldsymbol{A}_{i t} \boldsymbol{\gamma}+\boldsymbol{X}_{i t} \boldsymbol{\delta}+\mu_{t}+\varepsilon_{i t}
\end{aligned}
$$

Pooled OLS models assume that the variance of the cross-section specific effects $\left(\sigma_{i}\right)$ is zero $\left(\operatorname{var}\left(\sigma_{i}\right)=0\right)$. In the present setting such an assumption is likely to be violated. In order to relax this assumption, I estimate random effects (GLS) models that assume that the $\sigma_{i}$ 's result from a random draw and follow a normal distribution. I conduct Lagrange multiplier tests which indicate that $\operatorname{var}\left(\sigma_{i}\right) \neq 0$ and hence, the random effects estimates allowing for individual heterogeneity are the preferred specification. Due to the time persistence of the main explanatory variables (term length and term limits) I am not able to further relax the assumption and it is not possible to estimate fixed effects models allowing for arbitrary correlation between $\sigma_{i}$ and the explanatory variables, i.e., I cannot control for unobserved time-invariant heterogeneity. Only in the case of auditor 
expertise I can exploit at least some time variation and I present supplementary fixed effects results. Standard errors are adjusted for clustering at the state level, which allows for arbitrary correlations of the errors within states.

Since the audit offices differ along various dimensions, I also control for effects resulting from the different auditor selection and removal mechanisms and for differences in the audit mandate. ${ }^{16}$ Furthermore, all regressions include real per capita state debt $^{17}$ and a range of standard covariates controlling for state-specific heterogeneity. This is important in order to take structural differences between the states into account. I always start by presenting a basic regression model only including the most standard control variables (real per capita income, population size, unemployment rate, fraction of young and aged population, and a dummy for southern states) and then present further specifications controlling for time fixed effects.

\section{Empirical results}

Auditor tenure: First, I present results from regressions of credit ratings directly on tenure variables, which is similar to what has been done in many studies using corporate auditor data. The results show that data patterns in the present setup focusing on the public sector are similar to results from the corporate sector when analyzing actual auditor tenure.

Note that information on the actual auditor tenure is only available for the years between 1990 and 1996 (see Schelker 2008). Columns 1 and 2 present regression including the auditor tenure variables, state specific controls, and in column 2 year fixed effects. Likelihood ratio test show that including year effects improves model fit. Hence, all subsequent regressions include year fixed effects. The estimated effect of auditor tenure on GOB ratings is not statistically significant. The estimated coefficients for the control variables real per capita debt, the state population and the fraction of the aged population are negative and statistically significant while the coefficient of the log of real per capita income is positive and significant as well. The unemployment rate is negatively and the fraction of kids is positively correlated with GOB ratings, but these estimates are less robust. Across all estimated models, the included control variables are typically in line with previous research using state credit ratings (e.g., Depken and Lafountain 2006).

16. Not all states require the auditor to conduct exactly the same types of audit. In addition to standard financial audits several state auditors also conduct performance audits. Financial audits follow standard accounting rules and are comparable across states. The differences in the extent to which performance audits are conducted are controlled for in the empirical model.

17. Alternatively, real per capita government expenditures, debt to GDP ratios have been used individually as well as jointly and the main results are unaffected. However, model fit is best when only including real per capita debt. 
In column 3, I add the squared tenure variable to extract potential non-linear effects. Again the tenure variable is positive but not statistically significant while the squared tenure variable is negative but also not significant. Column 4 includes basic auditor control variables (election and removal procedures, audit mandate). When controlling for structural differences of the state auditing institution the estimates concerning auditor tenure become statistically significant at the 10 percent level. When further including major characteristics that are likely to co-determine auditor tenure - whether the auditor serves an open mandate (at the pleasure of the legislature) or a fixed predetermined term, the respective term length and whether or not there is a binding term limit - I find again a positive and significant effect of the tenure variable. Again, the squared tenure variable is negative but insignificant (column 5).

Including auditor variables, especially the term length and term limit variables, is not uncontroversial. These variables are important drivers of the actual auditor tenure, while at the same time they are likely to have a direct effect on audit quality. On the one hand, the length of a mandate and a potential term limit, for example, has direct effects on auditor incentives. A binding term limit decouples auditor incentives from the appointing body and potentially changes the interaction between the auditor and the auditee. Therefore, it seems that institutional variables have to be included in a meaningful regression. On the other hand, the fact that auditor tenure is likely to be influenced by the institutional setup leads to concerns related to multicollinearity. Given the low individual and joint correlations, however, this concern should not be overrated.

At first sight, instrumental variable regressions seem an easy fix of the endogeneity problem that is inherent when using actual auditor tenure. One could think that auditor tenure is driven by auditor characteristics such as the term length, term limit, etc. and assume at the same time that these variables only have an impact through the actual tenure length. However, the assumption that the instruments only influence outcomes through tenure length is clearly violated and hence, the exclusion restriction does not hold. Interestingly, even the correlations between auditor tenure and individual auditor characteristics are relatively weak. In the IV regression framework all combinations of instruments yield problems of weak instrument. All F-statistics of joint significance are never higher than 6. Therefore, estimating the influence of tenure length by using auditor characteristics as instruments does not yield useful insights. ${ }^{18}$

Auditor term length and term limits: Based on the arguments of the previous discussion the following results rely on measures which are not direct outcomes

18. G2SLS models including different sets of instrumental variables have been estimated. First, only the most defining variables, term length, term length square and open mandate were used as instruments. Next, I included the term limit variable and finally all auditor variables to the set of instruments. The instruments are weak and the exclusion restriction is violated. The instrumented tenure variable becomes negative and is typically not statistically significant. 
Table 1

The effect of auditor tenure on state GOB ratings

\begin{tabular}{|c|c|c|c|c|c|}
\hline \multicolumn{6}{|c|}{$\begin{array}{l}\text { Dependent variable: Standardized st } \\
\text { Estimation: Random Effects GLS }\end{array}$} \\
\hline & (1) & (2) & (3) & (4) & (5) \\
\hline Tenure length & $\begin{array}{c}0.001 \\
(0.001)\end{array}$ & $\begin{array}{c}0.000 \\
(0.001)\end{array}$ & $\begin{array}{c}0.002 \\
(0.001)\end{array}$ & $\begin{array}{c}0.002 * \\
(0.001)\end{array}$ & $\begin{array}{c}0.002 * \\
(0.001)\end{array}$ \\
\hline$(\text { Tenure length })^{2}$ & - & - & $\begin{array}{c}-6.82 \mathrm{e}-05 \\
(4.86 \mathrm{e}-05)\end{array}$ & $\begin{array}{c}-7.17 \mathrm{e}-05 \\
(4.90 \mathrm{e}-05)\end{array}$ & $\begin{array}{c}-6.70 \mathrm{e}-05 \\
(4.96 \mathrm{e}-05)\end{array}$ \\
\hline Term length & $\begin{array}{l}- \\
-\end{array}$ & - & $\begin{array}{l}- \\
-\end{array}$ & $\begin{array}{l}- \\
-\end{array}$ & $\begin{array}{l}-0.006 \\
(0.007)\end{array}$ \\
\hline Term limit & $\begin{array}{l}- \\
-\end{array}$ & $\begin{array}{l}- \\
-\end{array}$ & $\begin{array}{l}- \\
-\end{array}$ & $\begin{array}{l}- \\
-\end{array}$ & $\begin{array}{l}0.055^{* *} \\
(0.027)\end{array}$ \\
\hline Open mandate & $\begin{array}{l}- \\
-\end{array}$ & - & - & - & $\begin{array}{c}0.038 \\
(0.032)\end{array}$ \\
\hline Auditor election & $\begin{array}{l}- \\
-\end{array}$ & $\begin{array}{l}- \\
-\end{array}$ & $\begin{array}{l}- \\
-\end{array}$ & $\begin{array}{c}0.036 \\
(0.032)\end{array}$ & $\begin{array}{c}0.027 \\
(0.042)\end{array}$ \\
\hline Auditor removal & $\begin{array}{l}- \\
-\end{array}$ & $\begin{array}{l}- \\
-\end{array}$ & $\begin{array}{l}- \\
-\end{array}$ & $\begin{array}{c}0.003 \\
(0.003)\end{array}$ & $\begin{array}{c}0.003 \\
(0.003)\end{array}$ \\
\hline $\begin{array}{l}\text { Performance } \\
\text { audits }\end{array}$ & - & - & - & $\begin{array}{l}-0.024 \\
(0.017)\end{array}$ & $\begin{array}{l}-0.000 \\
(0.028)\end{array}$ \\
\hline Debt (real p.c.) & $\begin{array}{c}-1.8 \mathrm{e}-05 * * * \\
(5.75 \mathrm{e}-06)\end{array}$ & $\begin{array}{c}-1.8 \mathrm{e}-05 * * * \\
(5.56 \mathrm{e}-06)\end{array}$ & $\begin{array}{c}-1.8 \mathrm{e}-05 * * * \\
(5.21 \mathrm{e}-06)\end{array}$ & $\begin{array}{c}-2.4 \mathrm{e}-05^{* * *} \\
(6.21 \mathrm{e}-06)\end{array}$ & $\begin{array}{l}-2.18 \mathrm{e}-05 * * * \\
(4.54 \mathrm{e}-06)\end{array}$ \\
\hline Population & $\begin{array}{c}-3.1 \mathrm{e}-09 * * * \\
(9.41 \mathrm{e}-10)\end{array}$ & $\begin{array}{c}-3.2 \mathrm{e}-09 * * * \\
(9.00 \mathrm{e}-10)\end{array}$ & $\begin{array}{c}-3.3 \mathrm{e}-09 * * * \\
(9.16 \mathrm{e}-10)\end{array}$ & $\begin{array}{c}-4.1 \mathrm{e}-09 * * * \\
(1.01 \mathrm{e}-09)\end{array}$ & $\begin{array}{l}-3.81 \mathrm{e}-09 * * * \\
(1.21 \mathrm{e}-09)\end{array}$ \\
\hline Log income & $\begin{array}{l}0.141 * * * \\
(0.050)\end{array}$ & $\begin{array}{l}0.292 * * * \\
(0.078)\end{array}$ & $\begin{array}{l}0.297 * * * \\
(0.073)\end{array}$ & $\begin{array}{l}0.445^{* * *} \\
(0.118)\end{array}$ & $\begin{array}{l}0.405 * * * \\
(0.097)\end{array}$ \\
\hline$\%$ Unemployed & $\begin{array}{c}-0.001 \\
(0.002)\end{array}$ & $\begin{array}{c}-0.005 \\
(0.003)\end{array}$ & $\begin{array}{c}-0.006^{*} \\
(0.003)\end{array}$ & $\begin{array}{c}-0.007 * \\
(0.004)\end{array}$ & $\begin{array}{c}-0.006^{*} \\
(0.004)\end{array}$ \\
\hline$\%$ Aged & $\begin{array}{l}-1.032 * * \\
(0.444)\end{array}$ & $\begin{array}{c}-0.813^{* *} \\
(0.389)\end{array}$ & $\begin{array}{c}-0.892^{* *} \\
(0.371)\end{array}$ & $\begin{array}{c}-0.619 \\
(0.390)\end{array}$ & $\begin{array}{c}-0.690 * \\
(0.383)\end{array}$ \\
\hline$\%$ Kids & $\begin{array}{c}0.439 \\
(0.456)\end{array}$ & $\begin{array}{l}1.019 * * \\
(0.405)\end{array}$ & $\begin{array}{l}0.920 * * \\
(0.401)\end{array}$ & $\begin{array}{l}1.160 * * * \\
(0.384)\end{array}$ & $\begin{array}{l}1.195 * * * \\
(0.380)\end{array}$ \\
\hline Year Fixed Effects & no & yes & yes & yes & yes \\
\hline Observations & 299 & 299 & 299 & 261 & 261 \\
\hline $\mathrm{R}^{2}$ & 0.266 & 0.335 & 0.313 & 0.334 & 0.207 \\
\hline
\end{tabular}

Notes: Standard errors adjusted for clustering at state level in brackets. Dummy for southern states included. Significance level: $* 0.05<\mathrm{p}<0.1$, $* * 0.01<\mathrm{p}<0.05$, $* * * \mathrm{p}<0.01$. Source: Own calculations.

of individual auditor behavior or its bargaining position vis-à-vis the auditee, but rather the result of the institutional design defined in state constitutions and state laws. For the sake of legibility and clarity control variables will be omitted in subsequent tables.

Table 2 presents the regression results of auditor terms and term limits on state GOB ratings. Columns 1 and 2 show the basic estimates including term length and term limits. In columns 3 and 4 a dummy for auditors who serve open mandates is included. With this procedure I control for structural differences that 
Table 2

The effect of auditor term length and term limits on state GOB rating

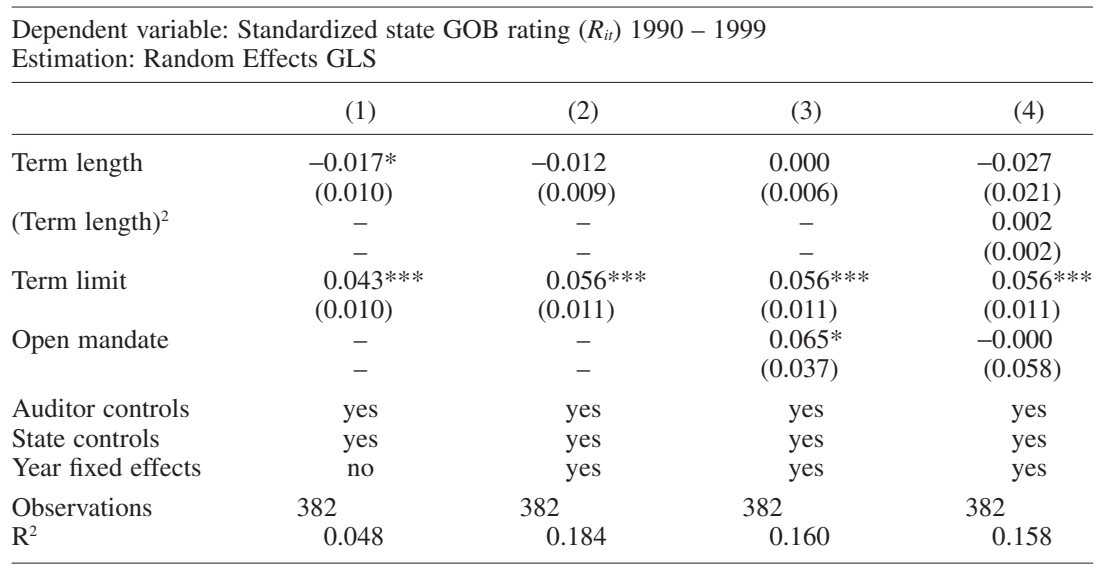

Notes: Standard errors adjusted for clustering at state level in brackets. Auditor controls: Election, Removal, Performance audits. State controls: Debt, Population, Log income, \% Unemployed, \% Aged, \% Kids, Dummy for southern states. Significance level: $* 0.05<\mathrm{p}<0.1$, ** $0.01<\mathrm{p}<0.05$, $* * * \mathrm{p}<0.01$. Source: Own calculations based on Schelker (2012a).

might exist between auditors with an open mandate - i.e., who serve at the pleasure of the appointing body - and auditors with a predetermined fixed term length - e.g., four years with the possibility of renewing the appointment. In column 5 and 6, I finally explore potential non-linear effects of auditor term length and add the squared term of the term length variable to the previously reported model specifications. Note that because the institutional design of auditors' office terms did not change during the sample period regression models including cross-section fixed effects cannot be estimated.

The estimated coefficient of the term length variable does not reach standard levels of statistical significance in any specification. The same is true when analyzing potential non-linear effects of auditor terms. The coefficient of the squared term length variable does never reach standard levels of statistical significance. In contrast, the estimated coefficient of the term limit variable, which in fact is a mandatory auditor rotation requirement, is positive and statistically significant across all estimated models and specifications (including Table 1). Hence, states that limit auditor terms are associated with significantly higher credit ratings. The overall magnitude of the effect is on average a roughly one notch higher credit rating for states in which the auditor faces a term limit (e.g., from AA to AA+).

Auditor expertise: Table 3 presents results when adding the measure of auditor expertise to the previous model specifications. Columns 1 and 2 report random 
Table 3

The effect of auditor expertise on state GOB ratings

\begin{tabular}{|c|c|c|c|c|}
\hline \multicolumn{5}{|c|}{ Dependent variable: Standardized state GOB rating $\left(R_{i t}\right) 1992-1999$} \\
\hline \multirow[t]{2}{*}{ Estimation } & Random Effects & Random Effects & Fixed Effects & Fixed Effects \\
\hline & (1) & (2) & (3) & (4) \\
\hline Expertise & $\begin{array}{l}0.036 * * * \\
(0.014)\end{array}$ & $\begin{array}{l}0.037 * * * \\
(0.014)\end{array}$ & $\begin{array}{l}0.056 * * * \\
(0.005)\end{array}$ & $\begin{array}{l}0.056^{* * *} \\
(0.005)\end{array}$ \\
\hline Term length & $\begin{array}{c}-0.000 \\
(0.005)\end{array}$ & $\begin{array}{c}-0.014 \\
(0.020)\end{array}$ & $\begin{array}{l}- \\
-\end{array}$ & $\begin{array}{l}- \\
-\end{array}$ \\
\hline$(\text { Term length })^{2}$ & $\begin{array}{l}- \\
-\end{array}$ & $\begin{array}{c}0.001 \\
(0.002)\end{array}$ & $\begin{array}{l}- \\
-\end{array}$ & - \\
\hline Term limit & $\begin{array}{l}0.045^{* * *} \\
(0.009)\end{array}$ & $\begin{array}{l}0.046^{* * *} \\
(0.009)\end{array}$ & $\begin{array}{l}- \\
-\end{array}$ & $\begin{array}{l}- \\
-\end{array}$ \\
\hline Open mandate & $\begin{array}{c}0.028 \\
(0.038)\end{array}$ & $\begin{array}{c}-0.006 \\
(0.058)\end{array}$ & - & - \\
\hline Auditor controls & yes & yes & dropped & dropped \\
\hline State controls & yes & yes & yes & yes \\
\hline Year fixed effects & yes & yes & no & yes \\
\hline State fixed effects & no & no & yes & yes \\
\hline Observations & 309 & 309 & 309 & 309 \\
\hline $\mathrm{R}^{2}$ & 0.229 & 0.220 & 0.041 & 0.055 \\
\hline
\end{tabular}

Notes: Standard errors adjusted for clustering at state level in brackets. Auditor controls: Election, Removal, Performance audits. State controls: Debt, Population, Log income, \% Unemployed, \% Aged, \% Kids, Dummy for southern states. Significance level: $* 0.05<\mathrm{p}<0.1, * * 0.01<\mathrm{p}<0.05$, $* * * \mathrm{p}<0.01$. Source: Own calculations based on Schelker $(2012 \mathrm{~b})$

effects estimates with and without year effects. The estimated coefficient is consistently positive and statistically significant. The results show that states demanding the auditor to hold at least a CPA feature significantly higher credit ratings. The supplementary regressions including cross-section (state) fixed effects in columns 3 and 4 show that the coefficient remains statistically significant, though, the impact is somewhat larger in magnitude. On average the states demanding the auditor to hold at least a CPA feature approximately a one notch higher credit rating than states without such a requirement. ${ }^{19}$

It is always very difficult to claim causal relationships going form auditor characteristics to credit ratings. Given the data limitations I cannot assertively rule out all concerns related to the potential endogeneity of auditor characteristics, even if such characteristics have been defined in the state constitution or in state laws many years before. Since the present institutional frameworks remained stable over time reverse causality should not be a major concern. However, simultaneity and omitted variable bias might still undermine causal inference. In order to reduce such bias a whole set of control variables is included and, where possible, cross-section fixed effects have been added to control for

19. Note that time-invariant variables cannot be estimated in a fixed effects framework. 
time-invariant unobserved heterogeneity (see also the discussion in Schelker $2012 a, b)$. In comparison to the endogeneity problems faced when analyzing corporate, non-experimental data, where auditor tenure and corporate outcomes are potentially direct functions of auditor performance and auditor independence the empirical hurdles seem less daunting. Given the stability of the institutional design and the strong and robust correlation of term limits and credit ratings, the evidence appears to be instructive for our purposes.

\section{SUMMARY AND CONCLUSION}

Reliable financial information is essential for investors and other stakeholders. Disclosure requirements are ineffective if the information provided is not accurate and timely. Therefore, disclosure requirements must be backed by independent review and legal rules enabling private litigation. Review of financial information is typically conducted by independent and certified auditing firms, which are supposed to verify and certify financial statements issued by a company's management. If the auditor is not competent and independent from the management, the audit of the financial statements loses its credibility.

The paper studies auditor expertise and the influence of mandatory auditor rotation as a measure to reduce the evolving ties between auditor and management over time. The proponents argue that auditor rotation is an important mechanism to secure auditor independence because the ties between management and auditor naturally become closer over time. Opponents in contrast argue that auditing requires firm- and industry-specific expertise and that auditor rotation destroys such know-how. They point to evidence that audit failure occurs with a higher probability in the beginning of a mandate. However, the empirical evidence on auditor rotation in the corporate sector suffers from serious endogeneity problems. If firm auditors are changed, the reasons for doing so are often correlated with some performance aspects. Either the auditor is incompetent or it is competent but too conservative in the eyes of the management. The latter change is obviously not desirable from an investor's point of view. Thus, observed auditor rotation in the corporate sector is likely to be endogenous to audit quality and firm specific circumstances.

Given the close similarities of the structure of the agency problem in the corporate and the public sector I propose analyzing public auditing institutions. Public auditors supervise government agents on behalf of the citizens, the principal. Every US State features a public auditing institution analyzing official financial statements. I take advantage of variation in the institutional design of these auditors across the states. I focus on the impact of auditor expertise, term length, and term limits, which are essentially mandatory rotation requirements.

I find strong evidences for significantly higher credit ratings in states with auditor term limits. The term limit comes after a maximum of two consecutive 


\section{MARK SCHELKER}

terms of 4 years. Furthermore, I find a positive and significant correlation between auditor expertise - measured as a requirement of the chief auditor to hold at least a degree as a certified public accountant (CPA) - and credit ratings. I find no statistically significant effects of auditor term length or its squared term. The influence of term limits can be interpreted as mandatory auditor rotation of the chief auditor. In the case of corporate auditors, this is comparable to mandatory rotation of the lead partner in the audit firm. If the public and the corporate sector can be compared, the evidence suggests that auditor rotation need not be as detrimental as feared by its opponents.

A combination of a fixed term length with the possibility for the auditor to be reappointed or reelected for an additional term in a competitive process before the term limit becomes binding might be an interesting alternative to a mandatory rotation requirement after a first fixed term. Such a procedure would make it possible to preserve expertise while providing the flexibility to investors or an independent board to replace an incompetent or corruptible auditor. The mandatory rotation requirement could then be installed after a second term, for example, in order to prevent the negative effects of extended auditor-client relationships. It seems essential that the auditor is evaluated and potentially reappointed by a body not subject to the audits, preferably the shareholders themselves, if the board of directors cannot be made entirely independent from management. Furthermore, in order to make the appointing process competitive, it should be open to all qualified candidates or candidate firms.

\section{REFERENCES}

Acemoglu, Daron and Miles B. Gietzmann (1997). Auditor Independence, Incomplete Contracts and the Role of Legal Liability, European Accounting Review. 6(3): 355-375.

Aghion, Philippe and Jean Tirole (1997). Formal Authority and Real Authority in Organizations, Journal of Political Economy. 105: 1-29.

Agrawal, Anup and Sahiba Chadha (2005). Corporate Governance and Accounting Scandals, Journal of Law and Economics. 48(2): 371-406.

Antle, Rick (1984). Auditor Independence, Journal of Accounting Research 22(1): 1-20

Arel, Barbara, Richard G. Brody and Kurt Pany (2005). Audit Firm Rotation and Audit Quality. CPA Journal. 105: 36-41.

Alt, James E. and David Dreyer Lassen (2006). Fiscal transparency, political parties, and debt in OECD countries, European Economic Review. 50: 1403-1439.

Alt, James E., David Dreyer Lassen and Shanna Rose (2006). The Causes of Fiscal Transparency: Evidence from the American States, IMF Staff Papers.

Baiman, Stanley, Hohn H. Evans III and Nandu J. Nagarajan (1991). Collusion in Auditing, Journal of Accounting Research. 29(1): 1-18.

Bazerman, Max H., George Loewenstein and Don A. Moore (2002). Why Good Accountants Do Bad Audits, Harvard Business Review (November Issue): 96-102.

Bebchuk, Lucian A. and Jesse M. Fried (2003). Executive Compensation as an Agency Problem, Journal of Economic Perspectives. 17(3): 71-92.

Bebchuk, Lucian A. (2007). The Myth of the Shareholder Franchise, Virginia Law Review. 93: $675-732$. 


\section{AUDITORS AND CORPORATE GOVERNANCE}

Becht, Marco, Patrick Bolton and Ailsa Röell (2003). Corporate Governance and Control, in: G.M. Constantinides \& M. Harris \& R. M. Stulz (ed.). Handbook of the Economics of Finance. 1(1):1-109.

Beiner, Stefan, Wolfgang Drobetz, Frank Schmid and Heinz Zimmermann (2004). Is Board Size an Independent Corporate Governance Mechanism? Kyklos. 57(3). 327-356.

Besley, Timothey and Michael Smart (2007). Fiscal Restraints and Voter Welfare, Journal of Public Economics. 91: 755-773.

Benz, Matthias and Bruno S Frey (2007). Corporate Governance: What can we learn from public governance? Academy of Management Review. 32(1): 92-104.

Bolton, Patrick and Mathias Dewatripont (2005). Contract Theory. MIT Press, Cambridge, Massachusetts.

Cameran, Mara, Dino di Vincenzo and Emilia Merlotti (2005). The Audit Firm Rotation Rule: A Review of the Literature, Working Paper, Bocconi School of Management.

Caramanis, Constantinos and Clive Lennox (2008). Audit effort and earnings management, Journal of Accounting and Economics. 45: 116-138.

Casterella, Jeffrey R. and Derek Johnston (2013). Can the academic literature contribute to the debate over mandatory audit firm rotation?, Research in Accounting Regulation. Forthcoming.

Chen, Chih-Ying, Chan-Jane Lin and Yu-Chen Lin (2008). Audit Partner Tenure, Audit Firm Tenure, and Discretionary Accruals: Does Long Auditor Tenure Impair Earnings Quality? Contemporary Accounting Research. 25(2): 415-45.

Church, Bryan K. and Ping Zhang (2006). A Model of Mandatory Auditor Rotation, Rotman School of Management Working Paper No. 07-08.

Comunale, Christie L. and Thomas R. Sexton (2005). Mandatory Auditor Rotation and Retention: Impact on Market Share, Managerial Auditing Journal. 20(3). 235-248.

Currall, Steven C. and Mark J. Epstein. (2003). The Fragility of Organizational Trust: Lessons From the Rise and Fall of Enron, Organizational Dynamics. 32: 193-206.

Davidson III, Wallace N., Pornsit Jiraporn and Peter DaDalt (2006). Causes and Consequences of Audit Shopping: An Analysis of Auditor Opinion, Earnings Management, and Auditor Changes, Quarterly Journal of Business and Economics. 45(1\&2): 69-87.

Depken, Craig A. and Courtney L. Lafountain (2006). Fiscal consequences of public corruption: empirical evidence from state bond ratings, Public Choice. 126: 75-85.

Dopuch, Nicholas, Ronald R. King and Rachel Schwartz (2001). An Experimental Investigation of Retention and Rotation Requirements, Journal of Accounting Research. 39(1). 93-117.

Fama, Eugene and Micheal Jensen (1983). Separation of Ownership and Control, Journal of Law and Economics. 26(2): 301-325.

Ferejohn, John (1999). Accountability and authority: toward a theory of political accountability, in: Przeworski, Adam, Susan C. Stokes and Bernard Manin (eds.), Democracy, accountability, and representation. Cambridge University Press: 131-153.

Ferguson, Andrew, Jere R. Francis, Donald J. Stokes (2003). The Effects of Firm-Wide and OfficeLevel Industry Expertise on Audit Pricing, The Accounting Review. 78(2): 429-448.

Frey, Bruno S. and Matthias Benz (2005). Can Private Learn from Public Governance? Economic Journal. 115: F377-F396.

GAO (2003). Public Accounting Firms. Required Study on the Potential Effects of Mandatory Audit Firm Rotation. United States General Accounting Office, November 2003.

Gavazza, Alessandro and Alessandro Lizzeri (2009). Transparency and Economic Policy, Review of Economic Studies. 76: 1023-1048.

Gosh, Aloke and Doocheol Moon (2005). Auditor Tenure and Perception of Audit Quality, The Accounting Review. 80(2): 585-612.

Gietzmann, Miles B. and Pradyot K. Sen (2002). Improving Auditor Independence Through Selective Mandatory Rotation. International Journal of Accounting. 6: 183-210. 


\section{MARK SCHELKER}

Gompers, Paul, Joy Ishii and Andrew Metrick (2003). Corporate Governance and Equity Prices, Quarterly Journal of Economics. 118(1): 107-155.

Gul, Ferdinand A., Simon Yu Kit Fung and Bikki Jaggi (2009). Earnings quality: Some evidence on the role of auditor tenure and auditors' industry expertise, Journal of Accounting and Economics. 47: 265-287.

Hermalin, Benjamin E. and Michael S. Weisbach (1998). Endogenously Chosen Boards of Directors and Their Monitoring of the CEO, American Economic Review. 88(1): 96-118

Hertzberg, Andrew, Jose Maria Liberti and Daniel Paravisini (2010). Information and Incentives Inside the Firm: Evidence from Loan Officer Rotation, Journal of Finance. 65: 795-828.

Jenkins, David S. and Uma Velury (2008). Does auditor tenure influence the reporting of conservative earnings? Journal of Accounting and Public Policy. 27: 115-132.

Jensen, Micheal and William H. Meckling (1976). Theory of the Firm: Managerial Behavior, Agency Costs and Ownership Structure, Journal of Financial Economics. 3(4): 305-360.

Johnson, Van E., Inder K. Khurana and J. Kenneth Reynolds (2002). Audit-firm Tenure and the Quality of Financial Reports, Contemporary Accounting Research. 19(4): 637-660.

Johnson, Craig L. and Kenneth A. Kriz (2005). Fiscal institutions, credit ratings, and borrowing costs, Public Budgeting and Finance. Spring: 84-103.

Kaplan, Steven E. and Elaine G. Mauldin (2008). Auditor rotation and the appearance of independence: Evidence from non-professional investors, Journal of Accounting and Public Policy. 27: 177-192.

Khalil, Fahad and Jacques Lawarrée (2006). Incentives for Corruptible Auditors in the Absence of Commitment, Journal of Industrial Economics. 54(2): 269-291.

Klein, April (1998). Firm Performance and Board Committee Structure, Journal of Law and Economics. 41(1). 275-303.

Kofman, Fred and Jacques Lawarrée (1993). Collusion in Hierarchical Agency, Econometrica. 61(3): 629-656.

Lai, Kam-Wah (2009). Does audit quality matter more for firms with high investment opportunities? Journal of Accounting and Public Policy. 28: 33-50.

La Porta, Rafael, Florencio Lopez-de-Silanes and Andrei Shleifer (2006). What Works in Securities Laws? Journal of Finance. 61(1): 1-32.

Latusek, Dominika and Karen S. Cook (2012). Trust in Transitions, Kyklos. 65(4): 512-525.

Levitt, Arthur (2000). Renewing the Covenant with Investors, Speech by the SEC Chairman at NYU, May 2000. http://www.sec.gov/news/speech/spch370.htm

Mansi, Sattar A., William F. Maxwell and Darius P. Miller (2004). Does Auditor Quality and Tenure Matter to Investors? Evidence from the Bond Market, Journal of Accounting Research. 42(4): 755-793.

Mayhew, Brian W. and Joel E. Pike (2004). Does Investor Selection of Auditors Enhance Auditor Independence? The Accounting Review. 79(3): 797-822.

McLean, Bethany and Peter Elkind (2003). The Smartest Guys in the Room: The Amazing Rise and Scandalous Fall of Enron. Penguin Group, New York.

Myers, James N., Linda A. Myers and Thomas C. Omer (2003). Exploring the Term of the AuditorClient Relationship and the Quality of Earnings: A Case for Mandatory Auditor Rotation? The Accounting Review. 78(3): 779-799.

NASACT (1989, 1992, 1996, 2000, 2002-2006). Auditing in the states: a summary, National Association of State Auditors, Comptrollers and Treasurers (NASACT). Lexington.

Olken, Benjamin A. (2007). Monitoring Corruption: Evidence from a Field Experiment in Indonesia. Journal of Political Economy. 115(2): 200-249.

Prendergast, Canice (1999). The Provision of Incentives in Firms. Journal of Economic Literature. 37(1): 7-63.

Schelker, Mark (2008). Making Auditors Effective: Theory, Evidence, Perspectives. Nomos, Baden-Baden. 


\section{AUDITORS AND CORPORATE GOVERNANCE}

Schelker, Mark (2012a). The influence of auditor term length and term limits on US state general obligation bond ratings, Public Choice. 150: 27-49.

Schelker, Mark (2012b). Auditor Expertise: Evidence from the Public Sector, Economics Letters. 116: 432-435.

Schelker, Mark and Reiner Eichenberger (2003). Starke Rechnungsprüfungskommissionen: Wichtiger als direkte Demokratie und Föderalismus? Ein erster Blick auf die Daten, Swiss Journal of Economics and Statistics. 139(3): 351-373.

Shivdasani, Anil and David Yermack (1999). CEO Involvement in the Selection of New Board Members: An Empirical Analysis, Journal of Finance. 54(5): 1829-1853.

Shleifer, Andrei and Robert W. Vishny (1997). A Survey of Corporate Governance, Journal of Finance. 52(2): 737-783.

Tirole, Jean (1986). Hierarchies and Bureaucracies: On the Role of Collusion in Organizations, Journal of Law, Economics and Organization. 2(2): 181-214.

Weisbach, Michael S. (1988). Outside Directors and CEO Turnover, Journal of Financial Economics. 20: 431-460.

\section{APPENDIX}

Table Al

Auditor variable description

\section{Tenure length}

Consecutive years in office.

Term length

Official auditor term length. Code: official term length in years; if the auditor serves 'at pleasure of legislature, legislative committee, etc.' then coded as 0.

\section{Term limit}

Binding term limit. Code: 0 if no term limit; 1 if binding term limit installed (2 terms of 4 years).

\section{Expertise}

Minimal professional education requirement for the chief auditor. Code: 0 if no minimal education requirement; 1 if minimal professional requirement is to hold at least a diploma of Certified Public Accountant (CPA)

\section{Election}

Selection procedure for agency head. Possible procedures: Elected by the citizens; appointed by the legislature, legislative committee, the executive. Code: 1 if elected by the citizens; 0 if appointed.

\section{Removal}

Removal procedure for agency head. Code: 0 if single committee or public official can remove agency head, 1 if simple majority vote in both legislative chambers required, 2 if supermajority required in both chambers or if special procedures required (e.g., impeachment with supermajority in at least one house, or involving judicial branch), 3 if agency head cannot be removed during official term.

\section{Performance audits}

Index adding all 3 types of performance audits: Economy \& Efficiency, Program, and Compliance audits.

Economy \& efficiency audits

Economy \& Efficiency audit. Code: 1 if economy and efficiency audit is conducted; 0 otherwise. Program audits

Program audit. Code: 1 if program audit is conducted; 0 otherwise.

Compliance audits

Compliance only audit. Code: 1 if compliance audit is conducted; 0 otherwise.

Notes: Main source of information on US state auditing institutions:

Auditing in the States: A Summary. National Association of State Auditors, Comptrollers and Treasurers (NASACT). 1989, 1992, 1996, 2000.

For more information on the construction of the dataset see Schelker (2008). 


\section{MARK SCHELKER}

Table A2

Summary statistics

\begin{tabular}{|c|c|c|c|}
\hline Variable & Min. - Max. & $\begin{array}{l}\text { Sample mean } \\
\text { (Std. Dev.) }\end{array}$ & Description \\
\hline $\begin{array}{l}\text { Credit rating } \\
\quad\left(R_{i t}\right)\end{array}$ & $-0.350--0.047$ & $\begin{array}{c}-0.129 \\
(0.058)\end{array}$ & $\begin{array}{l}\text { Moody's, S\&P \& Fitch normalized } \\
\text { state general obligation bond rating } \\
\text { (highest rating (AAA }=-1, \\
\text { AA }+=-2, \text { AA }=-3 \text {, etc., } \\
\text { normalized to a range between }-1 \\
\text { and } 0 \text { ) }\end{array}$ \\
\hline Tenure length & $0-41$ & $\begin{array}{c}8.777 \\
(7.856)\end{array}$ & $\begin{array}{l}\text { State auditors consecutive years in } \\
\text { office. }\end{array}$ \\
\hline Term length & $0-10$ & $\begin{array}{l}3.037 \\
(2.628)\end{array}$ & $\begin{array}{l}\text { Office term length of state auditor (in } \\
\text { years). }\end{array}$ \\
\hline Term limit & $0 / 1$ & $\begin{array}{c}0.088 \\
(0.284)\end{array}$ & $\begin{array}{l}\text { State auditor faces term limit }(1) \text {, } \\
\text { otherwise }(0)\end{array}$ \\
\hline Open mandate & $0 / 1$ & $\begin{array}{c}0.678 \\
(0.468)\end{array}$ & $\begin{array}{l}\text { If auditor serves at pleasure of } \\
\text { appointing body (1), if office term } \\
\text { length predetermined }(0)\end{array}$ \\
\hline Expertise & $0 / 1$ & $\begin{array}{c}0.219 \\
(0.414)\end{array}$ & $\begin{array}{l}\text { Minimum education requirement: } \\
\text { State auditor has to hold a CPA (1), } \\
\text { no minimum requirement }(0) \text {. }\end{array}$ \\
\hline Auditor election & $0 / 1$ & $\begin{array}{c}0.353 \\
(0.478)\end{array}$ & $\begin{array}{l}\text { State auditor is elected by the citizens } \\
\text { (1), auditor is appointed by the } \\
\text { legislature }(0) \text {. }\end{array}$ \\
\hline $\begin{array}{l}\text { Performance } \\
\text { audits }\end{array}$ & $0-3$ & $\begin{array}{c}1.853 \\
(1.128)\end{array}$ & $\begin{array}{l}\text { Index of performance audits } \\
\text { conducted by state auditor. }\end{array}$ \\
\hline Auditor removal & $0-3$ & $\begin{array}{l}1.22 \\
(0.934)\end{array}$ & $\begin{array}{l}\text { Index capturing removal procedures } \\
\text { for the state auditor. }\end{array}$ \\
\hline Debt (real p.c.) & $2366.41-23575.21$ & $\begin{array}{c}5053.18 \\
(2483.51)\end{array}$ & $\begin{array}{l}\text { Real per capita government debt in } \\
\text { USD }\end{array}$ \\
\hline Population & $550000-2.00 \mathrm{E}+07$ & $\begin{array}{c}5343362 \\
(4622413)\end{array}$ & Total state population \\
\hline Income & $10023.86-22913.7$ & $\begin{array}{l}14677.58 \\
(2371.28)\end{array}$ & Real per capita state income in USD \\
\hline$\%$ & $2.7-11.3$ & $\begin{array}{c}5.725 \\
(1.491)\end{array}$ & Unemployment rate \\
\hline$\%$ Aged & $0.084-0.188$ & $\begin{array}{c}0.128 \\
(0.018)\end{array}$ & Fraction of the aged population $(65+)$ \\
\hline$\%$ Kids & $0.153-0.269$ & $\begin{array}{c}0.187 \\
(0.018)\end{array}$ & $\begin{array}{l}\text { Fraction of school-aged population } \\
\quad(5-17)\end{array}$ \\
\hline
\end{tabular}

\section{SUMMARY}

Corporate auditors review and evaluate financial statements. Audit quality depends on auditor expertise and independence. To enhance auditor independence the selection process and auditor rotation requirements have been debated intensively. The available empirical evidence is not conclusive and suffers from serious endogeneity problems. I propose learning from the public sector where auditors play a similar role and present empirical evidence on the impact of auditor expertise, term length and rotation requirements on government performance at the US state level. I find evidence indicating that greater auditor expertise and rotation requirements have a positive effect on state credit ratings. 